\author{
Aleksandra Matulewska* \\ Adam Mickiewicz University in Poznań \\ Poland
}

\title{
SOCIALLY INDUCED CHANGES IN LEGAL TERMINOLOGY
}

\begin{abstract}
The author intends to present evolutionary and revolutionary changes in legal terminology. Legal terminology changes as a result of language usage, technological development, political and social changes and even economy reasons. The following research methods have been applied: the terminological analysis of the research material (empirical observation, analysis of comparable texts and parametric approach to legal terminology comparison) and the analysis of pertinent literature. The research material included legislation from the United Kingdom, the United States of America, Canada and Australia. The author focuses on terminological changes resulting from social transformations. Selected terms and their transformation in respect to meaning and form are elaborated on in the paper. Finally, the author draws conclusions that translation of such terminology should aim at communication precision and many of them may be false friends in interlingual communication.
\end{abstract}

Keywords: legal terminology, legal translation, legal terminology transformations.

\section{Introduction}

The paper is intended to provide an insight into some evolutionary and revolutionary changes in legal terminology in English. Natural languages evolve continually. Some of them disappear with the death of the last user and some of them strive for developing. Languages for specific purposes, including the language of the law, are subject to similar changes. Some professions cease to exist as there is no longer a need to practice them. Others develop and undergo metamorphoses. They are affected by the development of new technologies, social and political changes. The aim of this paper is to present some exemplary evolutionary and revolutionary changes that may be observed in the legal language which result from various factors. In this paper the author will focus on some examples of terminology evolution induced by social changes. 
This approach is based on the following research methods:

1. the terminological analysis of the research material

a. empirical observation,

b. analysis of comparable texts (cf. Neubert 1996, Delisle et al. 1999, Lewandowska-Tomaszczyk 2005, Roald \& Whittaker 2010), and

c. parametric approach to comparison of legal terminology (also called the method of axiomatisation of the legal linguistic reality (Bogusławski 1986, Bańczerowski \& Matulewska 2012, Matulewska 2013),

2. the analysis of pertinent literature.

The research material has included selected legislation for the Republic of Poland, the United Kingdom, the United States of America, Canada and Australia.

\section{Reasons and methods of legal terminology transformations}

There are numerous reasons for terminology transformations. Among them we may enumerate changes resulting from: (i) social transformations including life-style, (ii) political regime transformations, (iii) development of sciences, (iv) recognizing loopholes, (v) recognizing no longer enforced laws, (vi) international contacts and pressure, (vii) economic reasons, (ix) globalization, etc. Of course the list of reasons is far from being exhaustive, nevertheless, it may serve illustrative purposes and is sufficient for presenting and understanding examples described in more detail below.

The most popular methods of terminology transformation include:

(i) narrowing down the meaning of already existing terms (without changing their morphological or syntactic properties),

(ii) narrowing down the meaning of already existing terms by changing their morphological or syntactic properties,

(iii) broadening the meaning of already existing terms (without changing their morphological or syntactic properties),

(iv) broadening the meaning of already existing terms by changing their morphological or syntactic properties,

(v) completely changing the meaning of already existing terms (without changing their morphological or syntactic properties),

(vi) completely changing the meaning of already existing terms by changing their morphological or syntactic properties, 
(vii) coining new terms,

(viii) transplanting into the language for specific purposes terms already coined in a vernacular language,

(ix) borrowing terms from other languages (non-assimilated direct borrowings, assimilated direct borrowings, calques, hybrids).

Apart from the analysis of the terminology transformations the author has also resorted to the classification of nominal syntagms by Bańczerowski et al (1982: 249-253) into:

(i) determinational, and

(ii) coordinative.

The determinational ones include:

(i) concordial (Bańczerowski 1997: 53-69), in other words case agreement (cf. Bańczerowski et al 1982),

(ii) rectional syntagms (Bańczerowski 1988: 1159-1182), in other words case government (cf. Bańczerowski et al 1982),

(iii) multiword determiantional syntagms (Bańczerowski 1980: 90).

The coordinative syntagms include

(i) hypotactic syntagms,

(ii) paratactic syntagms and

(iii) appositional syntagms (cf. also Polański 1999, Machowski 2015)

\section{Socially-conditioned changes}

Social changes and pressure also affect legal languages. In general, legislation is amended as a result of various changes that may be observed in every-day, scientific and business life. Various social reasons lay behind resorting to various stylistic figures when coining new terminology such as, for instance, euphemisms. Let us quote Garner (2002) who remarks that:

Many legal euphemisms originated in a Victorian sensibility. Our digests of the law, for example, include sections under the phrase disorderly houses because writers considered whorehouses or brothels or bordellos too indelicate. (The non-legal euphemism is house of ill fame or repute). Despite its appearance, criminal conversation is not a legal doctrine that runs afoul of the First Amendment; the phrase refers to adulterous sex (which, of course, inevitably interferes with conjugal felicity). Only recently have we sloughed off the overzealous euphemizing about homosexuality, known formerly as the abominable and detestable crime against nature. Although some euphemisms, like the last one, are terribly slanted, others result from an understandable desire to sound objective, by avoiding biased words of the past. Extramarital, 
for example, strikes us as more neutral than adulterous (as used in the previous paragraph). And many legal writers are now inclined to use non-marital children or children out of wedlock instead of illegitimate children or, worse yet, bastards. Why indeed scar the innocent children with ugly epithets. (Garner 2002: 34)

Such changes are especially visible in various countries in legislation concerning the so called same-sex marriages. The juxtaposition of terminology used in four English-speaking countries where same-sex marriages are recognized and registered is provided in tables below. Those countries are the United Kingdom, Australia, Canada and the United States of America.

In the United Kingdom such unions are among others regulated by the Civil Partnership Act 2004 which regulates the relationship in England and Wales, Scotland and Northern Ireland and they are called civil partnerships:

Civil partnership

(1) A civil partnership is a relationship between two people of the same sex ("civil partners") -

(a) which is formed when they register as civil partners of each other -

(i) in England or Wales (under Part 2),

(ii) in Scotland (under Part 3),

(iii) in Northern Ireland (under Part 4), or

(iv) outside the United Kingdom under an Order in Council made under Chapter 1 of Part 5 (registration at British consulates etc. or by armed forces personnel), or

(b) which they are treated under Chapter 2 of Part 5 as having formed (at the time determined under that Chapter) by virtue of having registered an overseas relationship.

The legal consequences of marriages and civil partnerships in the United Kingdom are the same. The name "civil partnership" has been introduced for several reasons, one of them being sensitivity to people who associate marriage as a union of a man and a woman and have strong religious beliefs in that respect (cf. Herring 2007, 1-15). The term has been coined from the noun partner and the suffix - ship pre-modified with an adjective civil (thus it is a determinational concordial syntagm). Thus a new term has been coined to denote a relationship newly recognized under the law.

Citizens did not need to wait for the new wave of changes long. The years 2013 and 2014 have brought a significant change in the meaning of terminology in that respect. The semantic changes have been introduced by the Marriage (Same Sex Couples) Act 2013 and the Marriage and Civil Partnership (Scotland) Act 2014. Those two acts in fact broadened the meaning of the term "marriage" to include "same-sex couples". 
As a result of law amendments right now in England, Wales and Scotland there are same-sex couples who have been registered as civil partnerships (between 2004 and 2013 in England and Wales or 2014 in Scotland) and those who have been registered as marriages (of persons of the same sex starting from 2013 in England and Wales or 2014 in Scotland).

Table 1

\section{Juxtaposition of terminology used in the United Kingdom}

\begin{tabular}{|c|c|c|c|c|c|c|}
\hline $\begin{array}{l}\text { Name of } \\
\text { the union }\end{array}$ & $\begin{array}{l}\text { Legislation or } \\
\text { legal grounds } \\
\text { where the term } \\
\text { is used }\end{array}$ & $\begin{array}{l}\text { Territory } \\
\text { where } \\
\text { the law is } \\
\text { applicable }\end{array}$ & Quotation from legislation & $\begin{array}{l}\text { same- } \\
\text { sex } \\
\text { union }\end{array}$ & $\begin{array}{l}\text { opposite- } \\
\text { sex } \\
\text { union }\end{array}$ & $\begin{array}{l}\text { Name } \\
\text { of the } \\
\text { partner }\end{array}$ \\
\hline $\begin{array}{l}\text { civil } \\
\text { partner- } \\
\text { ships }\end{array}$ & $\begin{array}{l}\text { The Civil } \\
\text { Partnership } \\
\text { Act 2004 } \\
\text { (c 33) (UK) }\end{array}$ & $\begin{array}{l}\text { UK } \\
\text { (England } \\
\text { and Wales, } \\
\text { Scotland, } \\
\text { Northern } \\
\text { Ireland) }\end{array}$ & $\begin{array}{l}\text { "A civil partnership is a re- } \\
\text { lationship between two peo- } \\
\text { ple of the same sex" }\end{array}$ & yes & no & $\begin{array}{l}\text { civil } \\
\text { partner }\end{array}$ \\
\hline $\begin{array}{l}\text { marriage } \\
\text { (since 2013) }\end{array}$ & $\begin{array}{l}\text { the Marriage } \\
\text { (Same Sex } \\
\text { Couples) } \\
\text { Act } 2013\end{array}$ & $\begin{array}{l}\text { England } \\
\text { and Wales }\end{array}$ & $\begin{array}{l}\text { "Extension of marriage } \\
\text { to same sex couples. Mar- } \\
\text { riage of same sex couples is } \\
\text { lawful." }\end{array}$ & yes & yes & spouse \\
\hline $\begin{array}{l}\text { marriage } \\
\text { (since 2014) }\end{array}$ & $\begin{array}{l}\text { Marriage } \\
\text { and Civil } \\
\text { Partnership } \\
\text { (Scotland) } \\
\text { Act 2014 }\end{array}$ & Scotland & $\begin{array}{l}\text { " } 4 \text { Meaning of marriage and } \\
\text { related expressions in enact- } \\
\text { ments and documents } \\
\text { (1) References (however } \\
\text { expressed) in any enact- } \\
\text { ment to - } \\
\text { (a) marriage (including } \\
\text { a marriage that has ended), } \\
\text { (b) a person who is (or was) } \\
\text { married to another person, } \\
\text { and } \\
\text { (c) two people who are } \\
\text { (or were) married to each } \\
\text { other, are references to mar- } \\
\text { riage whether between per- } \\
\text { sons of different sexes or } \\
\text { persons of the same sex } \\
\text { and to a party (or for- } \\
\text { mer party), or as the case } \\
\text { may be the parties (or } \\
\text { former parties), to such } \\
\text { a marriage." }\end{array}$ & yes & yes & spouse \\
\hline
\end{tabular}

As the legislation puts it, as far as terminology is concerned, we deal with "marriage and related expressions" in the legal reality of England, Wales, Scotland and Northern Ireland. As far as semantic relations between them are concerned, we need to refer to the date of the execution of the document in which a given term is used. The meaning of the term mar- 


\section{Aleksandra Matulewska}

riage for instance has been extended by the Marriage (Same Sex Couples) Act 2013 and it encompasses both marriage between persons of different sexes or persons of the same sex. Thus the term right now is bound by the relation hypernym-hyponym with the terms (i) marriage used till the moment the act entered into force as previously the term marriage referred to marriages between persons of different sexes only and (ii) civil partnership referring to unions between persons of same sexes. The terms marriage referring to marriages between persons of different sexes only and civil partnership referring to unions between persons of same sexes were bound by the relation of co-hyponymy between 2004 and 2013. However, it should be borne in mind that the enactment of the Marriage (Same Sex Couples) Act 2013 and the Marriage and Civil Partnership (Scotland) Act 2014 has not resulted in the disappearance of civil partnerships. Under The Marriage of Same Sex Couples (Conversion of Civil Partnership) Regulations 2014 in England and Wales "the parties to a civil partnership may convert their civil partnership into a marriage". Nevertheless, the Act does not refer to persons in the Northern Ireland and Scotland (but the Scottish law has been amended by the said 2014 Act). Therefore, the term marriage under the law of England, Wales and Scotland right now is bound by the relation hypernym-hyponym with the Scottish term marriage (which still refers to the union of persons of the opposite sex).

In Australia depending on the territory in question the following terms are used:

1. civil partnerships for which registration is in force under the Civil Partnerships Act 2008 of the Australian Capital Territory and registered partnerships (having a wider sense and including both homoand hetero-sexual couples) in the Domestic Relationships Act 1994 and the Births, Deaths and Marriages Registration Act 1997 in the Australian Capital Territory,

2. civil partnerships under the Civil Partnership Act 2011 of Queensland,

3. significant relationships for which deeds of relationship have been registered, and are in force, under the Relationships Act 2003 of Tasmania,

4. registered domestic relationships within the meaning of the Relationships Act 2008 of Victoria.

The linguistics structure of terms civil partnership and significant relationship is the same as in the case of the British term - they are determinational concordial syntagms. However, it should be stressed here that the British term and the terms used in the Australian Capital Territory as well as Queensland are homographs (as they are spelled in an identical way) but their meaning is not exactly the same as the British civil partnership is used 
Table 2

\section{Juxtaposition of terminology used in some jurisdictions registering same-sex marriages in Australia}

\begin{tabular}{|c|c|c|c|c|c|c|}
\hline $\begin{array}{l}\text { Name of } \\
\text { the union }\end{array}$ & $\begin{array}{l}\text { Legislation or } \\
\text { legal grounds } \\
\text { where the term } \\
\text { is used }\end{array}$ & $\begin{array}{l}\text { Territory } \\
\text { where } \\
\text { the law is } \\
\text { applicable }\end{array}$ & Quotation from legislation & $\begin{array}{l}\text { same- } \\
\text { sex } \\
\text { union }\end{array}$ & $\begin{array}{l}\text { opposite- } \\
\text { sex } \\
\text { union }\end{array}$ & $\begin{array}{l}\text { Name } \\
\text { of the } \\
\text { partner }\end{array}$ \\
\hline $\begin{array}{l}\text { civil } \\
\text { partnership }\end{array}$ & $\begin{array}{l}\text { the Civil } \\
\text { Partnerships } \\
\text { Act } 2008 \text { of } \\
\text { the Australian } \\
\text { Capital } \\
\text { Territory }\end{array}$ & $\begin{array}{l}\text { Australian } \\
\text { Capital } \\
\text { Territory }\end{array}$ & $\begin{array}{l}\text { "Civil partnerships - gen- } \\
\text { eral } \\
\text { (1) This Act provides } \\
\text { a way for } 2 \text { adults who } \\
\text { are in a relationship as } \\
\text { a couple, regardless of } \\
\text { their sex, to have their } \\
\text { relationship legally recog- } \\
\text { nised by registration as } \\
\text { a civil partnership." }\end{array}$ & yes & yes & $\begin{array}{l}\text { civil } \\
\text { partner }\end{array}$ \\
\hline $\begin{array}{l}\text { significant } \\
\text { relation- } \\
\text { ships }\end{array}$ & $\begin{array}{l}\text { the Relation- } \\
\text { ships Act } 2003 \\
\text { of Tasmania }\end{array}$ & Tasmania & $\begin{array}{l}\text { "Significant relationships } \\
\text { (1) For the purposes of } \\
\text { this Act, a significant } \\
\text { relationship is a relation- } \\
\text { ship between two adult } \\
\text { persons - } \\
\text { (a) who have a relation- } \\
\text { ship as a couple; and } \\
\text { (b) who are not married } \\
\text { to one another or related } \\
\text { by family." }\end{array}$ & yes & yes & partner \\
\hline $\begin{array}{l}\text { registered } \\
\text { domestic } \\
\text { relation- } \\
\text { ships }\end{array}$ & $\begin{array}{l}\text { the Relation- } \\
\text { ships Act } 2008 \\
\text { of Victoria }\end{array}$ & Victoria & $\begin{array}{l}\text { "S. } 39(1) \text { def. of domestic } \\
\text { relationship amended by } \\
\text { No. } 4 / 2009 \text { s. } 19(1)(\mathrm{b}) \text {. } \\
\text { 'domestic relationship' } \\
\text { means - (a) a regis- } \\
\text { tered domestic relation- } \\
\text { ship; or (b) a relationship } \\
\text { between two persons who } \\
\text { are not married to each } \\
\text { other but who are living } \\
\text { together as a couple on } \\
\text { a genuine domestic basis } \\
\text { (irrespective of gender)" }\end{array}$ & yes & yes & $\begin{array}{l}\text { domestic } \\
\text { partners }\end{array}$ \\
\hline $\begin{array}{l}\text { civil } \\
\text { partnership }\end{array}$ & $\begin{array}{l}\text { the Civil } \\
\text { Partnership } \\
\text { Act } 2011 \text { of } \\
\text { Queensland }\end{array}$ & Queensland & $\begin{array}{l}\text { "4 Civil partnerships - } \\
\text { general (1) A civil part- } \\
\text { nership is a legally recog- } \\
\text { nised relationship that, } \\
\text { subject to this Act, may } \\
\text { be entered into by any } 2 \\
\text { adults, regardless of their } \\
\text { sex." }\end{array}$ & yes & yes & $\begin{array}{l}\text { civil } \\
\text { partner }\end{array}$ \\
\hline $\begin{array}{l}\text { interstate } \\
\text { registered } \\
\text { relation- } \\
\text { ships }\end{array}$ & $\begin{array}{l}\text { Relationships } \\
\text { Register } \\
\text { Regulation } \\
2010\end{array}$ & $\begin{array}{l}\text { New South } \\
\text { Wales }\end{array}$ & $\begin{array}{l}\text { "sec } 4 .(\ldots) \text { The following } \\
\text { classes of relationships } \\
\text { are interstate registered } \\
\text { relationships for the pur- } \\
\text { poses of the Act: (a) sig- } \\
\text { nificant relationships for }\end{array}$ & yes & yes & $\begin{array}{l}\text { they } \\
\text { recognize } \\
\text { unions } \\
\text { registered } \\
\text { somewhere } \\
\text { else }\end{array}$ \\
\hline
\end{tabular}




\begin{tabular}{|l|l|l|l|l|l|l|}
\hline $\begin{array}{c}\text { Name of } \\
\text { the union }\end{array}$ & $\begin{array}{c}\text { Legislation or } \\
\text { legal grounds } \\
\text { where the term } \\
\text { is used }\end{array}$ & $\begin{array}{c}\text { Territory } \\
\text { where } \\
\text { the law is } \\
\text { applicable }\end{array}$ & Quotation from legislation & $\begin{array}{c}\text { same- } \\
\text { sex } \\
\text { union }\end{array}$ & $\begin{array}{c}\text { opposite- } \\
\text { sex } \\
\text { union }\end{array}$ & $\begin{array}{c}\text { Name } \\
\text { of the } \\
\text { partner }\end{array}$ \\
\hline & & $\begin{array}{l}\text { which deeds of relation- } \\
\text { ship have been regis- } \\
\text { tered, and are in force, } \\
\text { under the Relationships } \\
\text { Act 2003 of Tasmania, } \\
\text { (b) registered domestic } \\
\text { relationships within the } \\
\text { meaning of the Relation- } \\
\text { ships Act 2008 of Victo- } \\
\text { ria, (c) civil partnerships } \\
\text { for which registration is } \\
\text { in force under the Civil } \\
\text { Partnerships Act 2008 of } \\
\text { the Australian Capital } \\
\text { Territory." }\end{array}$ & & \\
\hline
\end{tabular}

only in reference to same-sex marriages whereas the Australian terms refer to relationships that may be registered between persons of the same as well as opposite sex. From the translator's point of view they are false friends and may be misleading for translation recipients. What is more, all terms presented above are euphemisms and in none of those syntagms the noun marriage is used. If we add to the equation potential other names for various relationships between people that may be encountered in legal texts, it is clearly visible that utmost care needs to be exercised when interpreting the text and translating it into another language. Without establishing the precise meaning in reference to a specific legal system it is almost impossible to make a translational decision. Therefore, extreme care must be exercised when dealing with names of such partnerships or relationships in course of translation as the meanings of the terms are not always equivalent. For instance, in Relationships Act of 2003 of Tasmania four types of relationships are distinguished, that is to say:

1. significant relationships (which subsists between two adult persons living as a couple),

2. caring relationships (which subsists as a "a relationship other than a marriage or significant relationship between two adult persons whether or not related by family, one or each of whom provides the other with domestic support and personal care"),

3. personal relationships (which is either a significant or caring relationship) - is a hypernymic term in respect to its two co-hyponyms significant relationship and caring relationship, 
4. family relationships (which subsists between persons "related by family if (a) one is the parent, or another ancestor, of the other; or (b) one is the child, or another descendant, of the other; or (c) they have a parent in common",

5. interstate registered relationships under the Relationships Register Regulation 2010.

All terms mentioned above are determinational concordial syntagms, with the last one being multiword determinational concordial syntagm. They are mostly new terms coined to denote a relationship newly recognized under the law with the exception of family relationships.

In Canada the terminology is also quite diverse. For instance, the following terms may be found in relevant legislation of Canada:

1. union civile/civil union in Quebec under the Civil Code of Quebec as amended and the Act instituting civil unions and establishing new rules of filiation may subsist between parties who can be of the same or opposite sex which is to a large extent similar to marriage (which is a determinational concordial syntagm),

2. common-law relationship in Manitoba may subsist between parties who can be of same or opposite sex (major amendments enacted in 2001, cf. the Common-Law Partners Property and Related Amendments Act) but no explicit definition is used apart from the fact that the words 'man and woman' have been replaced with the noun 'person' implicitly suggesting that the relationship may subsist between persons of any gender (which is a determinational rectional syntagm),

3. domestic partnership in Nova Scotia subsists between two persons who are living in a conjugal relationship and who wish to form a domestic partnership (they may make the declaration); the parties can be of same or opposite sex under the Law Reform (2000) Act (the full title of which is Act to Comply with Certain Court Decisions and to Modernize and Reform Laws in the Province) - the definition is provided in the form of a negative enumeration informing who may not be a domestic partner (which is a determinational concordial syntagm),

4. adult interdependent relationship in Alberta encompassing a very wide scope of relationships including family bonds (which is a multiword determinational concordial syntagm).

Canadian terminology has been coined to denote a relationship newly recognized under the law. 
Table 3

\section{Juxtaposition of terminology used in some jurisdictions registering same-sex marriages in Canada}

\begin{tabular}{|c|c|c|c|c|c|c|}
\hline $\begin{array}{l}\text { Name of } \\
\text { the union }\end{array}$ & $\begin{array}{l}\text { Legislation or } \\
\text { legal grounds } \\
\text { where the term } \\
\text { is used }\end{array}$ & $\begin{array}{l}\text { Territory } \\
\text { where } \\
\text { the law is } \\
\text { applicable }\end{array}$ & Quotation from legislation & $\begin{array}{l}\text { same- } \\
\text { sex } \\
\text { union }\end{array}$ & $\begin{array}{l}\text { opposite- } \\
\text { sex } \\
\text { union }\end{array}$ & $\begin{array}{l}\text { Name } \\
\text { of the } \\
\text { partner }\end{array}$ \\
\hline $\begin{array}{l}\text { union civile/ } \\
\text { civil union }\end{array}$ & $\begin{array}{l}\text { the Civil } \\
\text { Code of } \\
\text { Quebec as } \\
\text { amended } \\
\text { and the Act } \\
\text { instituting } \\
\text { civil unions } \\
\text { and estab- } \\
\text { lishing new } \\
\text { rules of } \\
\text { filiation }\end{array}$ & Quebec & $\begin{array}{l}\text { The Civil Code: " } 521.1 \\
\text { A civil union is a com- } \\
\text { mitment by two persons } \\
18 \text { years of age or over who } \\
\text { express their free and en- } \\
\text { lightened consent to share } \\
\text { a community of life and to } \\
\text { uphold the rights and obli- } \\
\text { gations that derive from } \\
\text { that status. A civil union } \\
\text { may only be contracted } \\
\text { between persons who are } \\
\text { free from any previous bond } \\
\text { of marriage or civil union } \\
\text { and who in relation to each } \\
\text { other are neither an ascen- } \\
\text { dant or a descendant, nor } \\
\text { a brother or a sister." } \\
\text { The Act instituting civil } \\
\text { unions and establishing } \\
\text { new rules of filiation "This } \\
\text { bill creates an institution, } \\
\text { the civil union, for cou- } \\
\text { ples of the opposite or the } \\
\text { same sex who wish to make } \\
\text { a public commitment to live } \\
\text { together as a couple and to } \\
\text { uphold the rights and obli- } \\
\text { gations stemming from such } \\
\text { status" }\end{array}$ & yes & yes & $\begin{array}{l}\text { civil } \\
\text { union } \\
\text { spouse }\end{array}$ \\
\hline $\begin{array}{l}\text { common-law } \\
\text { relationship }\end{array}$ & $\begin{array}{l}\text { Common- } \\
\text { Law } \\
\text { Partners } \\
\text { Property } \\
\text { and Related } \\
\text { Amend- } \\
\text { ments Act }\end{array}$ & Manitoba & $\begin{array}{l}\text { "Definition } \\
\text { 1. In this Act, "common- } \\
\text { law partner" of a person } \\
\text { means } \\
\text { (a) another person who, } \\
\text { with the person, registered } \\
\text { a common-law relationship } \\
\text { under section } 13.1 \text { of The } \\
\text { Vital Statistics Act, and } \\
\text { who is cohabiting with the } \\
\text { person, or } \\
\text { (b) another person who, not } \\
\text { being married to the per- } \\
\text { son, is cohabiting with him } \\
\text { or her in a conjugal rela- } \\
\text { tionship and has so cohab- } \\
\text { ited } \\
\text { (i) for a period of at least } \\
\text { three years, or }\end{array}$ & yes & yes & $\begin{array}{l}\text { common- } \\
\text { law } \\
\text { partner }\end{array}$ \\
\hline
\end{tabular}


Socially Induced Changes in Legal Terminology

\begin{tabular}{|c|c|c|c|c|c|c|}
\hline $\begin{array}{l}\text { Name of } \\
\text { the union }\end{array}$ & $\begin{array}{l}\text { Legislation or } \\
\text { legal grounds } \\
\text { where the term } \\
\text { is used }\end{array}$ & $\begin{array}{l}\text { Territory } \\
\text { where } \\
\text { the law is } \\
\text { applicable }\end{array}$ & Quotation from legislation & $\begin{array}{l}\text { same- } \\
\text { sex } \\
\text { union }\end{array}$ & $\begin{array}{c}\text { opposite- } \\
\text { sex } \\
\text { union }\end{array}$ & $\begin{array}{l}\text { Name } \\
\text { of the } \\
\text { partnes }\end{array}$ \\
\hline & & & $\begin{array}{l}\text { (ii) for a period of at least } \\
\text { one year and they are } \\
\text { together the parents of } \\
\text { a child. } \\
14(3) \text { Subsection 19(2) is } \\
\text { amended } \\
\text { (a) in the part before } \\
\text { clause (a), by striking out } \\
\text { "married man or a married } \\
\text { woman" and substituting } \\
\text { "married person or a person } \\
\text { who is a common-law part- } \\
\text { ner"; and } \\
\text { (b) in the part after } \\
\text { clause (b), by adding "or } \\
\text { common-law partner" after } \\
\text { "spouse". } \\
14 \text { (4) Section 24 is amended } \\
\text { (a) by striking out "married } \\
\text { man or a married woman" } \\
\text { and substituting "person"; } \\
\text { (b) by adding "or common- } \\
\text { law partner" after "spouse" } \\
\text { wherever it occurs; and } \\
\text { (c) by striking out "the } \\
\text { married man or the mar- } \\
\text { ried woman" wherever it } \\
\text { occurs and substituting "the } \\
\text { person"." }\end{array}$ & & & \\
\hline $\begin{array}{l}\text { domestic } \\
\text { partnership }\end{array}$ & $\begin{array}{l}\text { the Law Re- } \\
\text { form (2000) } \\
\text { Act the } \\
\text { full title of } \\
\text { which is Act } \\
\text { to Comply } \\
\text { with Certain } \\
\text { Court Deci- } \\
\text { sions and to } \\
\text { Modernize } \\
\text { and Reform } \\
\text { Laws in the } \\
\text { Province }\end{array}$ & $\begin{array}{l}\text { Nova } \\
\text { Scotia }\end{array}$ & $\begin{array}{l}\text { " } 32 \text { Section } 2 \text { of Chap- } \\
\text { ter } 494 \text { of the Revised } \\
\text { Statutes, } 1989 \text {, the Vital } \\
\text { Statistics Act, as amended } \\
\text { by Chapter } 8 \text { of the Acts } \\
\text { of } 1998 \text {, is further amended } \\
\text { by adding immediately af- } \\
\text { ter clause (h) the following } \\
\text { clause: } \\
\text { (ha) "domestic partnership" } \\
\text { means a relationship be- } \\
\text { tween two persons who have } \\
\text { filed a domestic-partner } \\
\text { declaration in accordance } \\
\text { with Part II; } \\
52 \text { In this Part, } \\
\text { (a) "domestic partner" } \\
\text { means an individual who } \\
\text { is a party to a registered } \\
\text { domestic-partner declara- } \\
\text { tion made in accordance } \\
\text { with Section } 53 \text { and does } \\
\text { not include a former domes- } \\
\text { tic partner; (...) }\end{array}$ & yes & yes & \\
\hline
\end{tabular}




\begin{tabular}{|c|c|c|c|c|c|c|}
\hline $\begin{array}{l}\text { Name of } \\
\text { the union }\end{array}$ & $\begin{array}{l}\text { Legislation or } \\
\text { legal grounds } \\
\text { where the term } \\
\text { is used }\end{array}$ & $\begin{array}{l}\text { Territory } \\
\text { where } \\
\text { the law is } \\
\text { applicable }\end{array}$ & Quotation from legislation & $\begin{array}{c}\text { same- } \\
\text { sex } \\
\text { union }\end{array}$ & $\begin{array}{l}\text { opposite- } \\
\text { sex } \\
\text { union }\end{array}$ & $\begin{array}{l}\text { Name } \\
\text { of the } \\
\text { partner }\end{array}$ \\
\hline & & & $\begin{array}{l}53 \text { (1) Subject to this Sec- } \\
\text { tion, two individuals who } \\
\text { are cohabiting or intend } \\
\text { to cohabit in a conjugal } \\
\text { relationship may make } \\
\text { a domestic-partner dec- } \\
\text { laration in the prescribed } \\
\text { form. (...)" }\end{array}$ & & & \\
\hline $\begin{array}{l}\text { adult } \\
\text { inter- } \\
\text { dependent } \\
\text { relationships }\end{array}$ & $\begin{array}{l}\text { Adult Inter- } \\
\text { dependent } \\
\text { Relation- } \\
\text { ships Act. } \\
\text { Statutes } \\
\text { of Alberta, } \\
2002 \text { Chap- } \\
\text { ter A-4.5 }\end{array}$ & Alberta & $\begin{array}{l}\text { "Interpretation 1(1) In this } \\
\text { Act, (a) "adult interde- } \\
\text { pendent partner" means } \\
\text { an adult interdependent } \\
\text { partner within the mean- } \\
\text { ing of section } 3 \text {, but does } \\
\text { not include a former adult } \\
\text { interdependent partner; } \\
\text { (b) "adult interdependent } \\
\text { partner agreement" means } \\
\text { an agreement referred to } \\
\text { in section 7; (c) "adult } \\
\text { interdependent relation- } \\
\text { ship" means the relation- } \\
\text { ship between } 2 \text { persons who } \\
\text { are adult interdependent } \\
\text { partners of each other;" } \\
\text { "Adult interdependent } \\
\text { partner } 3(1) \text { Subject to } \\
\text { subsection (2), a person } \\
\text { is the adult interdepen- } \\
\text { dent partner of another } \\
\text { person if (a) the person } \\
\text { has lived with the other } \\
\text { person in a relationship } \\
\text { of interdependence (i) for } \\
\text { a continuous period of not } \\
\text { less than } 3 \text { years, or (ii) of } \\
\text { some permanence, if there } \\
\text { is a child of the relation- } \\
\text { ship by birth or adoption, } \\
\text { or (b) the person has en- } \\
\text { tered into an adult interde- } \\
\text { pendent partner agreement } \\
\text { with the other person under } \\
\text { section } 7 \text {. (2) Persons who } \\
\text { are related to each other by } \\
\text { blood or adoption may only } \\
\text { become adult interdepen- } \\
\text { dent partners of each other } \\
\text { by entering into an adult in- } \\
\text { terdependent partner agree- } \\
\text { ment under section } 7 . "\end{array}$ & & & $\begin{array}{l}\text { Adult } \\
\text { inter- } \\
\text { dependent } \\
\text { partner }\end{array}$ \\
\hline
\end{tabular}


In the United States of America, before the Supreme Court decision of June 26, 2015, enforcing acceptance of same-sex marriages nationwide, there were states with bans on same-sex marriages. But in the wake of the fact that the US Supreme Court ruled that same-sex marriage is a constitutional right under the 14th Amendment to the Constitution the terminology is probably going to be unified in the whole country. The term used in the decision is same-sex marriage and the Court states a follows: "The Fourteenth Amendment requires States to recognize same-sex marriages validly performed out of State. Since same-sex couples may now exercise the fundamental right to marry in all States, there is no lawful basis for a State to refuse to recognize a lawful same-sex marriage performed in another State on the ground of its same-sex character" (https://pl.scribd.com/doc/2697 70065/Supreme-Court-Gay-Marriage-Ruling\#download\&from_embed).

But before the Supreme Court decisions, for instance, the following terms have been used:

1. civil union in Hawaii, New Jersey, Illinois, Rhode Island (which is a determinational concordial syntagm),

2. domestic partnerships in Nevada, Wisconsin, Maine, California, Washington State, District of Columbia (which is a determinational concordial syntagm),

3. reciprocal beneficiary relationships in Hawaii available to both same- and opposite-sex couples who for some reasons cannot get married (which is a multiword rectional syntagm).

4. designated beneficiary agreement in Colorado (which is a multiword rectional syntagm)

The term same-sex marriage is a coordinative syntagm which is a multiword modification of the term marriage.

In France there is the union which is called pacte civil de solidarité. The institution allows both same and opposite-sex couples register their relationships. Pacte civil de solidarité is translated literally into English as a civil solidarity pact (https://www.service-public.fr/particuliers/vosdroits/N144) which is a determinational concordial syntagm created to denote a new object of social reality.

Additionally, it should be stressed again that the meanings of those terms differ. Some of them refer to same-sex relationships only whereas others to both same-sex as well as opposite-sex unions. Some of them are invented not to use the term marriage in respect to homosexual couples, thus they may be considered euphemisms.

As a result of social changes described hereinabove also the definitions of some sexual crimes have evolved. The social acceptance for some sexual 


\section{Aleksandra Matulewska}

practices changes in time. Let us analyse the term buggery used in the British legal system. During the reign of Henry VIII the Parliament passed the socalled Buggery Act 1533 which was titled An Acte for the punishment of the vice of Buggerie. Buggery was defined as "the detestable and abominable Vice of Buggery committed with Mankind or Beast" (Bum, 1797, 233). As a result of court practice the meaning of the term, very vaguely formulated in the Act, was narrowed down and started to mean anal penetration and bestiality (nowadays called zoophilia that is to say sexual practices with non-humans - animals). The crime was punishable by death so in other words it was a capital offence. In 1828 the Offences against the Person Act was passed. Buggery was punished with death until 1861 when the Offences against the Person Act 1861 was passed. The Act of 1861 stated that "61. Whosoever shall be convicted of the abominable Crime of Sodomy and Buggery, committed either with Mankind or with any Animal, shall be liable, at the Discretion of the Court, to be kept in Penal Servitude for Life or for any Term not less than Ten Years." The Sexual Offences Act 1956 in its first version stated that "12.-(1) It is felony for a person to commit buggery with another person or with an animal. (2) Section thirty-nine of this Act (which relates to the competence as a witness of the wife or husband of the accused) does not apply in the case of this section, except on a charge of an offence with a person under the age of seventeen." The Sexual Offences Act 1956 as amended right now states that "Buggery. (1) It is felony for a person to commit buggery with another person otherwise than in the circumstances described in subsection (1A) or (1AA) below or with an animal. (1A) The circumstances first referred to in subsection (1) are that the act of buggery takes place in private and both parties have attained the age of sixteen. (1AA) The other circumstances so referred to are that the person is under the age of sixteen and the other person has attained that age. (1B) An act of buggery by one man with another shall not be treated as taking place in private if it takes place - (a) when more than two persons take part or are present; or (b)in a lavatory to which the public have or are permitted to have access, whether on payment or otherwise. (1C) In any proceedings against a person for buggery with another person it shall be for the prosecutor to prove that the act of buggery took place otherwise than in private or that one of the parties to it had not attained the age of sixteen." As we can see from the quoted sections of the Act, the definition has gradually been changed. It is no longer capital offence and it may not be considered an offence in many circumstances. Thus the term has been modified in respect to its meaning but not in respect to its morphological or syntactic properties. 
In that particular case we observe modification aiming at narrowing down the meaning.

Another term that may be enumerated here is carnal knowledge understood as the penetration of female organs by a male organ which in the United Kingdom is an archaism that has been replaced with a new term, that is to say sexual intercourse. Both terms are concordial syntagms. The term carnal knowledge is used in the Offences against the Person Act 1828 (section 18) and the Offences against the Person Act 1861 (section 63). In the Criminal Law Amendment Act 1885 - we can find a reference to "procuring unlawful carnal knowledge of woman by threats, false pretences or administering drugs", "unlawful carnal knowledge, or attempted unlawful carnal knowledge, of a girl under 14", as well as "unlawful carnal knowledge of a girl under 17". In the Sexual Offences Act of 1956 we no longer find carnal knowledge instead we have the term sexual intercourse which is defined as: "44. Where, on the trial of any offence under this Act, it is necessary to prove sexual intercourse (whether natural or unnatural), it shall not be necessary to prove the completion of the intercourse by the emission of seed, but the intercourse shall be deemed complete upon proof of penetration only." The replacement of the term is definitely a direct result of the impact of medical language on vernacular and, consequently, legal languages. Thus, it is the case of transplanting into the legal language a term already coined in other languages, where the previously used term becomes an archaism as a result of the replacement.

Similar socially-conditioned evolutionary changes of the meaning may be observed in respect to the term intestate successor / heir and intestate succession. Initially only legitimate children could succeed intestate. Children born out of wedlock were excluded and treated as inferior. That was mainly due to the fact that the Roman principles pater est, quem nuptiae demonstrant ("the father is he to whom marriage points") and mater semper certa est ("the mother is always certain") was applied for centuries in many countries. The developments in medicine have changed the situation and the Latin principle pater semper incertus est ("the father is always uncertain") (Kolańczyk 2007) is no longer applicable in the light of DNA tests that can verify or falsify paternity of the child. Additionally, the acceptance for not solemnized long-lasting relationships has been growing for decades. In many communities children born out of such unions are no longer stigmatized in daily life. However, they still may be discriminated against by succession law. The equalization of succession rights of legitimate and illegitimate issue is a relatively new concept in European countries and the USA (cf. Kerridge and Brierley 2009, Schreier 1980). Schreier in his article of 1980 


\section{Aleksandra Matulewska}

titled "Illegitimates' Intestate Succession Rights in New York: Is Further Liberalization Forthcoming?" still pointed out that despite some amendments the rights of illegitimates are far from being equal to those enjoyed by legitimates. However, there are still countries where children born out of wedlock may not inherit their father's property (cf. Mokobi 2015). In that case the equalization of rights to inherit enjoyed by legitimate and illegitimate children in fact leads to broadening of the meaning of the analysed determinational concordial syntagm.

\section{Concluding remarks}

The list of terms is by no means exhaustive and serves only illustrative purposes. The research is preliminary. The changes are challenging for both lawyers and translators. Both professionals participating in communication in legal settings need to take into account such metamorphoses as they may be important from the point of view of other communication participants.

If we take into account the tripartite concept of equivalence proposed by Šarčević (2000: 238-239), that is to say near equivalents, partial equivalents and non-equivalents where near equivalence is the case

when concepts A and B share all of their essential and most of their accidental characteristics (intersection) or when concept A contains all of the characteristics concept $\mathrm{B}$, and concept $\mathrm{B}$ all of the essential and most of the accidental characteristics of concept A (inclusion) (...). In the majority of cases functional equivalents are only partially equivalent. Partial equivalence occurs when concepts A and B share most of their essential and some of their accidental characteristics (intersection) or when concept A contains all of the characteristics of concept B but concept B only most of the essential and some of the accidental characteristics of concept A (inclusion). (...) If only a few or none of the essential features of concepts A and B coincide (intersection) or if concept A contains all of the characteristics of concept B but concept B only a few or none of the essential features of concept A (inclusion), then the functional equivalent can no longer be considered acceptable. In such cases, one speaks of non-equivalence. Furthermore, non-equivalence also occurs in cases where there is no functional equivalent in the target legal system for a particular source concept. In such cases one speaks of exclusion.

The question may be posed whether the term intestate successor or terms used to refer to unions of same-sex marriages, etc. and its counterparts in various legal systems may be treated as translational functional equivalents as they usually differ as far as their meaning is concerned, de- 
pending on the legal system they are used in. For instance the term intestate successor and its functional equivalents may differ in respect to the mode of property distribution between the spouse, parents and children of the deceased, fractional shares of property to which each of successors may be entitled, and persons excluded from succession. The issue is which of the characteristics of the terms in question should be considered essential and which accidental ones. If we assume that (i) the essential characteristics is the fact that a successor is appointed in the absence of the last will and testament and law is going to govern the division and distribution of the estate and (ii) the accidental features are the mode of property distribution between the spouse, parents and children of the deceased, fractional shares of property to which each of successors may be entitled, and persons excluded from succession, we may treat the terms as partially equivalent. However, if the essential features and the accidental features include the mode of property distribution between the spouse, parents and children of the deceased, fractional shares of property to which each of successors may be entitled, then the terms in many language pairs are no longer sufficiently equivalent and may need to be modified by descriptions amending for discrepancy in meaning.

Analogously, the term marriage under the law of England, Wales and Scotland and the term marriage under the US law are sufficiently equivalent, but at the same time the term marriage under the Northern Ireland law is not equivalent with the term marriage under the law of England, Wales and Scotland as well as the US law. Additionally, civil partnership under the Northern Ireland law as well as the same-sex marriage under the Supreme Court of the USA decision are sufficiently equivalent. However, the civil partnership under the UK law and Australian Capital Territory law differ as the former refers to unions of persons of the same sex concluded between 2004 and 2013 for England and Wales or 2014 for Scotland whereas the former to both same-sex and opposite-sex unions. Therefore, the terms may be considered false friends. Analogously, a false friend for the English term civil partnership is the Polish term spótka cywilna which used to be translated in the 90ties literally into English as civil partnership (as it is a business partnership formed under the provisions of the Polish Civil Code). Right now the recommended term for that form of business organization is civil proprietorship or civil law partnership. However, some bi-lingual Polish-English dictionaries still suggest the term civil partnership (cf. Łozińska-Małkiewicz and Małkiewicz 2005, 643). Moreover, some terms are invented to avoid using the term marriage in respect to homosexual couples, thus they may be euphemisms. In such instances possible trans- 


\title{
Aleksandra Matulewska
}

lations into other languages should take all those factors into account and provide equivalents modified appropriately not to mislead the translation recipient.

\author{
N O T E
}

* The research financed from the research grant no. DEC-2012/07/E/HS2/00678, titled: Parametrization of legilinguistic translatology in the scope of civil law and civil procedure awarded by the National Science Centre of the Republic of Poland (Sonata Bis program).

\section{R E F E R E N C E S}

Bańczerowski, J. \& Matulewska, A. 2012. Towards the Foundations of Legilinguistic Translatology. In P. Grzegorczyk, K. Knoppek \& M. Walasik (eds.), Proces cywilny. Nauka - Kodyfikacja - Praktyka. Ksiega jubileuszowa dedykowana Profesorowi Feliksowi Zedlerowi (1225-1261). Warszawa: Wolters Kluwer Polska.

Bańczerowski, J. 1980. Systems of Semantic and Syntax, Warszawa: Państwowe Wydawnictwo Naukowe.

Bańczerowski, J. 1988. 'A contribution to the theory of concord', in Basaj, Mieczysław \& Borek, Henryk (eds.), Wokót języka. Rozprawy i studia poświęcone pamięci Profesora Mieczystawa Szymczaka, Wrocław: Wydawnictwo Polskiej Akademii Nauk, 53-69.

Bańczerowski, J. 1997. 'A theory of rection', in Hickey, Raymond \& Puppel, Stanisław (eds.), Language History and Language Modelling: a Festschrift for Jacek Fisiak on His 60th Birthday, Vol. 2, Berlin: Mouton de Gruyter, 11581182.

Bańczerowski, J.; Pogonowski, J. and Zgółka, T. 1982. Wstęp do językoznawstwa, Poznań: Adam Mickiewicz University Press.

Bogusławski, A. 1986. O pojęciu wyjaśniania i wyjaśnianiu w lingwistyce. Biuletyn Polskiego Towarzystwa Językoznawczego. XL, 45-51.

Bum, R. 1797. Ecclesiastical Law: In Four Volumes, Vol. 1. London: W. Strahan and M. Woodhall, Law Printer to the King's moft Excellent Majesty. (https:// books.google.pl/books?id=MWJJAAAAYAAJ\&printsec $=$ frontcover\&hl=pl \&source=gbs_ge_summary_r\&cad $=0 \# \mathrm{v}=$ onepage $\& \mathrm{q} \& \mathrm{f}=$ false) .

Delisle J. et al. (eds.) 1999. Translation Terminology. Amsterdam/Philadelphia: John Benjamins Publishing Company.

Goddard, Ch. 2009. Where Legal Cultures Meet: Translating Confrontation into Coexistence. Investigationes Linguisticae vol. XVII, 168-205.

Herring, J. 2007. Family law. Law Express. Harlow: Pearson Longman. http://iate.europa.eu/FindTermsByLilId.do?lilId=1899646\&langId=en. 
Jopek-Bosiacka, A. 2010. Legal Communication: A Cross-Cultural Perspective. Warsaw: Warsaw University Press.

Kerridge, R., Brierley, A. H. R. 2009. The Law of Succession. London: Sweet \& Maxwell, Thomson Reuters.

Kolańczyk, K. 2007. Prawo rzymskie. Warszawa: LexisNexis.

Lewandowska-Tomaszczyk, B. 2005. Podstawy jezykoznawstwa komputerowego. Łódź: Wydawnictwo Uniwersytetu Łódzkiego.

Łozińska-Małkiewicz, E., Małkiewicz, J. 2005. Polsko-angielski słownik terminologii prawniczej. Torun: Wydawnictwo Ewa Jezry Małkiewicz.

Machowski, Sz. 2015. Compounding Properties and Translation Methods of Terms in the Domain of Infectious Diseases. In: ten Hacken, P., Panocova, R. (eds.). Word Formation and Transparency in Medical English. Newcastle upon Tyne: Cambridge Scholars Publishing, 179-200.

Matulewska, A. 2007. Lingua Legis in Translation. Frankfurt am Main, Germany: Peter Lang Publishing House.

Matulewska, A. 2013. Legilinguistic Translatology. A Parametric Approach to Legal Translation. Frankfurt am Main, Germany: Peter Lang Publishing House.

Matulewska, A. 2013. Legilinguistic Translatology. A Parametric Approach to Legal Translation. Frankfurt am Main, Germany: Peter Lang Publishing House.

Mokobi, E. M. 2015. Lingering Inequality in Inheritance Law: the Child Born Out Of Wedlock in Botswana. Anneke Meerkotter (ed.): Using the Courts to Protect Vulnerable People. Perspectives from the Judiciary and Legal Profession in Botswana, Malawi, and Zambia. Johannesburg: Southern Africa Litigation Centre, Judiciary of Malawi, National Association of Women Judges and Magistrates of Botswana (NAWABO) 140-148.

Neubert, A. 1996. Text linguistics of Translation: The Textual Approach to Translation. In R. M. Gaddis (ed.), Translation Horizons Beyond the Boundaries of Translation Spectrum. Translation Perspectives IX (87-105). Binghamton: Center for Research in Translation.

Polański, K. (ed.) 1999. Encyklopedia językoznawstwa ogólnego [Encyclopedia of General Linguistics]. Wrocław etc.: Ossolineum.

Rayar, L. 1992. Translating Law: Method or Madness? In J. Miller (ed.), International Forum of Legal Translation 1992. Proceedings (62-71). Warszawa: Wydawnictwo TEPIS.

Roald J., Whittaker S. 2010. Verbalisation in French and Norwegian Legislative Texts: A Contrastive Case Study. In M. Gotti \& Ch. Williams (eds.), Legal Discourse Across Languages and Cultures. Linguistic Insights 117 (95-107). Bern: Peter Lang.

Šaračević, S. 2000. New Approach to Legal Translation. The Hague: Kluwer Law International. 
Schreier, W. S. 1980. Illegitimates' Intestate Succession Rights in New York: Is Further Liberalization Forthcoming? Fordham Law Review, vol. 49, issue 3:379403.

\section{Selected source texts}

Act instituting civil unions and establishing new rules of filiation. Retrieved November 2016 from the website: http://www2.publicationsduquebec.gouv.qc.ca/ dynamicSearch/telecharge.php?type $=5 \&$ file=2002C6A.PDF .

Adult Interdependent Relationships Act, Statutes of Alberta, 2002 Chapter A4.5 Current as of May 14, 2014. Retrieved November 2016 from the website: http://www.qp.alberta.ca/documents/Acts/A04P5.pdf.

Buggery Act 1533 (An Acte for the punishment of the vice of Buggerie), Retrieved April 2015 from https://docs.google.com/document/d/18whzfJsPDo58sZO yJ2jj1DOjE9XVjvRlrV5S5HDdWdQ/edit.

Civil Code of 1964 of 23 April 1964 [Ustawa Kodeks Cywilny z dnia 23 kwietnia 1964 r.]. Retrieved April 2015 from the website of Kancelaria Sejmu http:// isap.sejm.gov.pl/DetailsServlet?id=WDU19640160093.

Civil Code of Quebec as amended. Retrieved November 2016 from the website: http://legisquebec.gouv.qc.ca/en/showdoc/cs/CCQ-1991.

Civil Partnership Act 2004 (c 33). Retrieved November 2016 from the website: http://www.legislation.gov.uk/ukpga/2004/33/contents.

Civil Partnership Act 2011 of Queensland. Retrieved November 2016 from the website: https://www.legislation.qld.gov.au/LEGISLTN/ACTS/2011/11AC 046.pdf.

Civil Partnerships Act 2008 of the Australian Capital Territory. Retrieved November 2016 from the website: http://www.austlii.edu.au/au/legis/act/num_ act/cpa200814o2008268/.

Common-Law Partners Property and Related Amendments Act. Retrieved November 2016 from the website: http://web2.gov.mb.ca/laws/statutes/2002/c04 802e.php.

Common-Law Partners' Property and Related Amendments Act. Retrieved November 2016 from the website: http://web2.gov.mb.ca/laws/statutes/2002/c04 802e.php.

Criminal Law Amendment Act 1885 referred to in Youth Justice and Criminal Evidence Act 1999. Retrieved in November 2016 from the website: http://www. legislation.gov.uk/ukpga/1999/23/contents?text=carnal\%20knowledge\#ma tch-1.

Law Reform (2000) Act (full title: Act to Comply with Certain Court Decisions and to Modernize and Reform Laws in the Province). Retrieved November 2016 from the website: http://nslegislature.ca/legc/bills/58th_1st/3rd_read /b075.htm.

Law Reform (2000) Act of Nova Scotia. Retrieved November 2016 from the website: http://nslegislature.ca/legc/bills/58th_1st/3rd_read/b075.htm. 
Marriage (Same Sex Couples) Act 2013. Retrieved December 2016 from the website: http://www.legislation.gov.uk/ukpga/2013/30/part/1/enacted

Marriage and Civil Partnership (Scotland) Act 2014. Retrieved December 2016 from the website: http://www.legislation.gov.uk/asp/2014/5/pdfs/asp_2014 0005_en.pdf.

Marriage of Same Sex Couples (Conversion of Civil Partnership) Regulations 2014 in England and Wales. Retrieved December 2016 from the website: http:// www.legislation.gov.uk/uksi/2014/3181/pdfs/uksi_20143181_en.pdf.

Offences against the Person Act 1828. Retrieved November 2016 from the website: https://en.wikisource.org/wiki/Offences_against_the_Person_Act_1828.

Offences against the Person Act 1861. Retrieved November 2016 from the website: http://www.legislation.gov.uk/ukpga/1861/100/pdfs/ukpga_18610100_en.pdf.

Pacte civil de solidarité. Retrieved November 2016 from https://www.servicepublic.fr/particuliers/vosdroits/N144.

Regulation (EU) No 650/2012 of the European Parliament and of the Council of 4 July 2012 on jurisdiction, applicable law, recognition and enforcement of decisions and acceptance and enforcement of authentic instruments in matters of succession and on the creation of a European Certificate of Succession, Retrieved November 2016 from http://eur-lex.europa.eu/legal-content/EN/ TXT/HTML/?uri=CELEX:32012R0650\&from $=$ EN.

Relationships Act 2003 of Tasmania. Retrieved November 2016 from the website: http://www.austlii.edu.au/au/legis/tas/consol_act/ra2003173/.

Relationships Act 2008 of Victoria. Retrieved November 2016 from the website: http://www.austlii.edu.au/au/legis/vic/consol_act/ra2008173/.

Relationships Register Regulation 2010. Retrieved November 2016 from the website: http://www.austlii.edu.au/au/legis/nsw/num_reg/rra2010rrr201020103 3611j2010720.pdf

Sexual Offences Act 1956 as amended http://www.legislation.gov.uk/ukpga/Eliz2 /4-5/69/section/12.

Sexual Offences Act 1956. Retrieved November 2016 from the website: http://www. legislation.gov.uk/ukpga/1956/69/pdfs/ukpga_19560069_en.pdf.

Supreme Court decision of June 26, 2015 (Supreme Court of the United States Syllabus Obergefell et al. v. Hodges, Director, Ohio Department of Health, et al. Certiorari to the United States Court of Appeals for the Sixth Circuit, No. 14-556. Argued April 28, 2015-Decided June 26, 2015). Retrieved November 2016 from the website: https://www.supremecourt.gov/opinions/ 14pdf/14-556_3204.pdf. 